\title{
Prostaglandin synthesis by, and the effects of prostaglandins and prostaglandin analogues on, the vas deferens of the rabbit and rat in vitro
}

\author{
Carol G. Swan and N. L. Poyser
}

Department of Pharmacology, University of Edinburgh, 1 George Square, Edinburgh EH8 9JZ, U.K.

\begin{abstract}
Summary. The endogenous concentrations of three PGs in the vas deferens of rabbits and rats were low (5-50 ng/100 mg tissue), although PGE-2 and PGF-2 $\alpha$ were present in greater quantities than 6-keto-PGF-1 $\alpha$. Homogenates of rat and rabbit vas deferens synthesized these three PGs in large quantities during a $90 \mathrm{~min}$ incubation period. PGE-2 was the major PG synthesized by the rat vas deferens, followed by PGF-2 $\alpha$ and 6-keto-PGF-1 $\alpha$. PG production by the rabbit vas deferens was lower than in the rat and PGF- $2 \alpha$ was the major PG formed.

None of the prostanoids tested (PGE-1, PGE-2, PGD-2, ICI 79939, ICI 81008 (fluoprostenol), 9,11-epoxymethano PGH-2, and 11,9-epoxymethano PGH-2) in concentrations up to $1-20 \mu \mathrm{g} / \mathrm{ml}$ altered the tone of the rabbit or rat vas deferens. PGI-2 was more potent than PGE-2 or PGF- $2 \alpha$ in potentiating responses of the rabbit vas deferens to noradrenaline but was less potent than PGF-2 or PGE-1 in inhibiting responses to field stimulation. No consistent effects of these three PGs on responses of the rat vas deferens to noradrenaline administration were observed. PGE-2 and PGE1 , but not PGI-2, had only a small inhibitory effect on the responses of the rat vas deferens to field stimulation. None of the other prostanoids tested affected the responses of the vas deferens to noradrenaline or to field stimulation in either species. It is concluded that, while PGs may not directly affect the tone of the vas deferens, they may affect the contractility of the vas deferens by pre-junctional actions in the rabbit and rat, and by post-junctional actions in the rabbit. These actions of PGs (confined to PGE-2, PGF-2 $\alpha$ and PGI-2) may influence sperm transport along the vas deferens.
\end{abstract}

\section{Introduction}

Prostaglandins (PGs) are present in high concentrations $(10-1000 \mu \mathrm{g} / \mathrm{ml})$ in the semen of primates, sheep and goats (Eliasson, 1959; Kelly, 1978). The source of these PGs is the seminal vesicles. Prostaglandin (PG) concentrations in the semen of most laboratory animals are low in comparison with those of primates (Eliasson, 1959; Horton \& Thompson, 1964; De Cuminsky \& Mercuri, 1971 ; Poyser, 1974). However, the content of PG-like substances in rat and mouse semen, assayed in terms of PGE-1, increases during mating to 1-2 $\mu \mathrm{g}$ per rat and 0.5-1 $\mu \mathrm{g}$ per mouse (Marley \& Smith, 1974a) and the source of these PGs is the vas deferens (Marley \& Smith, 1974b, 1975). Rabbit semen also contains-PGE-2 (70 ng/ml) and PGF-2 $\alpha(30 \mathrm{ng} / \mathrm{ml})$ (Poyser, 1974), but their source is not known. The endogenous concentrations of PGs in vas deferens tissue of the mouse and rat are higher than in other tissues in the reproductive tract (Badr, Barcikowski \& Bartke, 1975; 
Gerozissis \& Dray, 1980) and it has been suggested that PGs produced by the vas deferens are involved in the regulation of sperm transport through this tissue (Badr et al., 1975). PGE-2 has been reported to potentiate responses of the vas deferens to noradrenaline in the guinea-pig (von Euler \& Hedqvist, 1969; Ambache \& Zar, 1970; Hedqvist \& von Euler, 1972), rat and rabbit (Hedqvist \& von Euler, 1972). However, Bhagat, Dhalla, Ginn, La Montagne \& Montier (1970) found that PGE-2 inhibited the responses to noradrenaline in the guinea-pig and Clegg (1966) reported that PGE-1 and PGF- $2 \alpha$ both attenuated the responses of the rat vas deferens. The reasons for these discrepancies are not clear.

We have measured tissue levels of, and synthesizing capacity for, 6-keto-PGF-1 $\alpha$ (reflecting PGI-2 synthesis), PGE-2 and PGF- $2 \alpha$ in the vas deferens of the rat and rabbit and examined the direct effects of various PGs and PG analogues on the tone of the rabbit and rat vas deferens.

\section{Materials and Methods}

Fully adult New Zealand White rabbits weighing $2 \cdot 5-3 \mathrm{~kg}(\mathrm{~N}=6,20$ and 15 for Exps 1,2 and 3 respectively) and albino Wistar rats weighing $250-300 \mathrm{~g}(\mathrm{~N}=6$ for Exp. 1 and $\mathrm{N}=7$ for Exps 2 and 3 ) were stunned and killed by exsanguination. The vasa deferentia were quickly removed and were used in one of the following experiments.

Experiment 1. One vas deferens from each rat or rabbit was placed in ethanol and was freed from connective tissue. The contents of the lumen were flushed out. The vas deferens was weighed, homogenized in $15 \mathrm{ml}$ ethanol, centrifuged at $1000 \mathrm{~g}$ for $15 \mathrm{~min}$ and the supernatant fluid was withdrawn. The precipitate was washed with $5 \mathrm{ml}$ ethanol and was centrifuged at $1000 \mathrm{~g}$ for $15 \mathrm{~min}$; the washings were combined with the original extract. The extracts were evaporated to dryness, on a rotary evaporator at $45^{\circ} \mathrm{C}$, and were each re-dissolved in $10 \mathrm{ml}$ water.

The $\mathrm{pH}$ of each aqueous extract was lowered to 4.0 by the addition of $0.1 \mathrm{~N}-\mathrm{HCl}$ and the PGs present were extracted by shaking three times with $20 \mathrm{ml}$ ethyl acetate. The three ethyl acetate fractions were combined and evaporated to dryness on a rotary evaporator at $45^{\circ} \mathrm{C}$. Each residue was re-dissolved in ethyl acetate and stored at $-20^{\circ} \mathrm{C}$. The amounts of PGE-2, PGF-2 $\alpha$ and 6-keto$P G F-1 \propto$ present in each extract were measured by radioimmunoassay.

The other vas deferens was removed, weighed and homogenized in Krebs' solution (119 mM$\mathrm{NaCl}, 25 \mathrm{~mm}-\mathrm{NaHCO}_{3}, 4.7 \mathrm{~mm}-\mathrm{KCl}, 1.2 \mathrm{~mm}-\mathrm{KH}_{2} \mathrm{PO}_{4}, 2.5 \mathrm{~mm}-\mathrm{CaCl}_{2}, 1.0 \mathrm{~mm}-\mathrm{MgSO}_{4}$ and $11 \cdot 1$ $\mathrm{mM}-\mathrm{D}$-glucose), using $10 \mathrm{ml}$ and $15 \mathrm{ml}$ for tissue from rats and rabbits respectively, and incubated for $90 \mathrm{~min}$ at $37^{\circ} \mathrm{C}$, gassed with $95 \% \mathrm{O}_{2}, 5 \% \mathrm{CO}_{2}$. The $\mathrm{pH}$ of the incubate was then lowered to $\mathrm{pH} 4$ with $1 \mathrm{~N}-\mathrm{NCl}$ and the PGs extracted and stored as above, except that $30 \mathrm{ml}$ ethyl acetate were used for extracting the rabbit incubates. The amounts of PGE-2, PGF- $2 \alpha$ and 6-keto-PGF-1 $\alpha$ formed were measured by RIA. Control experiments in this laboratory have shown that the recovery of PGE-2 and PGF- $2 \alpha$ is greater than $90 \%$ (Poyser \& Scott, 1980) and the recovery of 6-keto-PGF- $1 \alpha$ is $81.5 \pm 2.01 \%$ from aqueous media by the methods used. None of the results obtained were corrected for recovery.

Experiment 2. Rabbit and rat vasa deferentia were mounted individually in a $10 \mathrm{ml}$ organ bath containing $\mathrm{K}$ rebs' solution at $37^{\circ} \mathrm{C}$, gassed with $95 \% \mathrm{O}_{2}, 5 \% \mathrm{CO}_{2}$, under $0.5 \mathrm{~g}$ tension. Contractions were recorded isometrically via a Grass FT03 C force displacement transducer coupled to a Servoscribe pen recorder. Tissues were allowed to equilibrate for $30 \mathrm{~min}$ before the addition of drugs. In the first series of experiments, the effects of PGE-1, PGE-2, PGD-2, PGF- $2 \alpha$, the PGF- $2 \alpha$ analogues, ICI 79939 and ICI 81008 (fluprostenol), and the TXA-2 mimics 9,11-epoxymethano PGH-2 and 11,9-epoxymethano PGH-2, on the resting tone of the rabbit and rat vas deferens were examined. In a second series of experiments, the effects of PGS on the responses elicited by noradrenaline were examined. In the initial experiments, it was observed that several of the PGs potentiated the response of the rabbit and rat vas deferens to noradrenaline when the PG was added $30 \mathrm{sec}$ before or after noradrenaline, although potentiation was greater when the PG was 
added afterwards. In the main experiments of this series, a log dose-response curve for noradrenaline was obtained on each tissue. Each dose was applied for $5 \mathrm{~min}$ and there were 10-min intervals between doses of noradrenaline. The effects of the various PGs on the log dose-response curve were estimated by adding the same doses of noradrenaline to the organ bath, followed $30 \mathrm{sec}$ later by the selected PG. The doses of the different PGs chosen were those that produced similar shifts in the $\log$ dose-response curve for noradrenaline so that the relative potencies of the PGs could be compared. In this experiment and in Exp. 3, regression lines were drawn through the appropriate points by computer to obtain the log dose-response relationship. In this experiment, the effect of adding phentolamine $\left(10^{-7} \mathrm{M}\right) 1 \mathrm{~min}$ before the addition of noradrenaline was also examined.

Experiment 3. A rabbit or rat vas deferens was set up in an organ bath as in Exp. 2 except that each vas deferens was subjected to field stimulation using a Grass S44 stimulator. Contractions were recorded isometrically by a Grass FT03 C force displacement transducer connected to a Grass polygraph. The stimulator delivered trains of rectangular pulses of $0.8 \mathrm{sec}$ duration at $20 \mathrm{~Hz}$, at supramaximal voltage for $5 \mathrm{sec}$ every $30 \mathrm{sec}$. Tissues were left responding to field stimulation for at least 30 min before adding PGs. Each PG was added to the organ bath between the stimulations and was washed out of the organ bath when a maximal effect was reached. The contractions were then allowed to return to normal, and remain at a normal level for $10 \mathrm{~min}$ before another addition of PG.

\section{Assay procedures}

Radioimmunoassays. PGF- $2 \alpha$ was measured by an antibody raised in rabbits (Dighe, Emslie, Henderson, Rutherford \& Simon, 1975). This antibody cross-reacts with PGF- $1 \alpha(100 \%)$, but has low cross-reactivity with other PGs and their metabolites (Poyser \& Scott, 1980). The limit of detection was $25 \mathrm{pg} /$ tube. PGE-2 was measured by an antibody raised in rabbits, which cross-reacts with PGE-1 (100\%), PGA-2 (13.6\%) and PGB-2 (260\%) but has low cross-reactivities with other PGs and their metabolites (Lytton \& Poyser, 1982a). The limit of detection was $25 \mathrm{pg} /$ tube. 6-KetoPGF- $1 \alpha$ was measured by an antibody which has low cross-reactivity with other PGs and PG metabolites (Poyser \& Scott, 1980). The detection limit was $25 \mathrm{pg} /$ tube. The intra-assay coefficients of variation, calculated from the variation between duplicate results, were $8 \cdot 6 \%$ (PGF- $2 \alpha), 9 \cdot 2 \%$ (PGE-2), and $8 \cdot 2 \%$ (6-keto-PGF-1 $\alpha$ ). The interassay coefficients of variation, calculated from the results obtained by incorporating a known amount of each compound into the appropriate assay, were $12 \cdot 3 \%$ (PGF- $2 \alpha), 4 \cdot 1 \%$ (PGE-2) and $10 \cdot 9 \%$ (6-keto-PGF-1 $\alpha$ ).

\section{Identification of PGs by gas chromatography-mass spectrometry (GC-MS)}

After being assayed, the extracts of one tissue type were combined to provide two samples. The samples were purified further and then subjected to analysis by GC-MS as described by Poyser (1983).

Drugs. The following drugs were used: noradrenaline bitartrate (Sigma, U.K.), bretylium (Burroughs Wellcome, London, U.K.), phentolamine (Ciba, Sussex, U.K.), PGs and PGH-2 analogues, except PGI-2 (Upjohn, Kalamazoo, Michigan, U.S.A.), ICI 79939 and ICI 81008 (I.C.I., Macclesfield, U.K.). PGI-2 (Schering Company, Berling-Bergkanen, W. Germany) was made up in carbonate buffer $\mathrm{pH} 8$, stored on ice and diluted with saline when required. PGI-2 was stable during a day's experiment under these conditions.

\section{Statistical tests}

The results are expressed as mean \pm s.e.m. Statistical significance was determined by Student's $t$ test. Parallelism of dose-response curves was assessed according to the method of Saunders \& Fleming (1957). 


\section{Results}

\section{Experiment 1}

Analysis by GC-MS showed that PGF- $2 \alpha$, PGE-2 and 6-keto-PGF-1 $\alpha$ were present in extracts from rat vas deferens. PGE-1, PGA-2, PGB-2 and PGF-1 $\alpha$ were not detected in these extracts. Unfortunately, the mass spectra of the rabbit extracts taken at the retention times of the authentic PGs contained too many m/e peaks for the m/e peaks due to any $\mathrm{PG}$ present to show clearly above the background 'biological noise'. Consequently, in spite of the extra purification step, the extracts of rabbit vas deferens still contained much higher levels of impurities than did the extracts of the rat vas deferens, thus making the GC-MS analysis of the rabbit extracts inconclusive. However, the PGE-2 antiserum was more likely to be measuring PGE-2 than PGB-2 since a biochemical pathway for the conversion of PGE-2 into PGB-2 has not been reported.

Endogenous concentrations of PGs in the rabbit and rat vas deferens were low (5-50 ng/100 ng tissue; Text-fig. 1). The major PGs present in both species were PGF-2 $\alpha$ and PGE-2 with lesser quantities of 6-keto-PGF-1 $\alpha$.
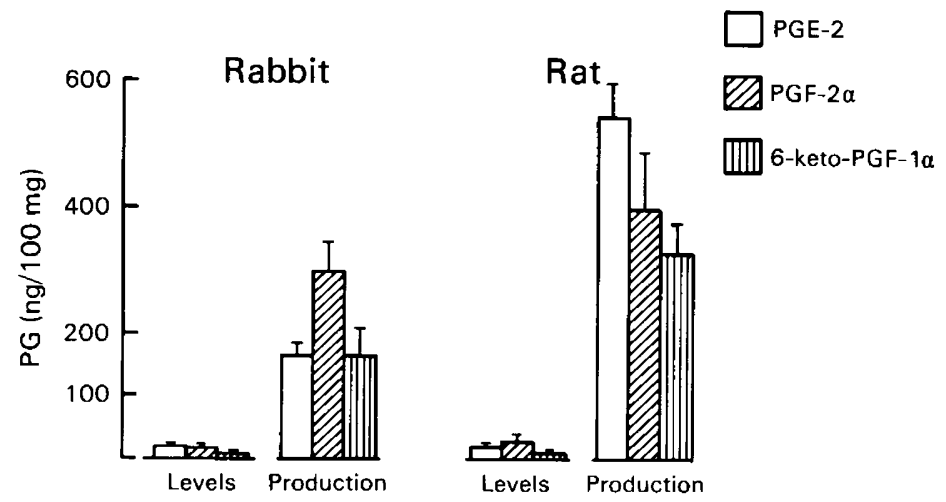

Text-fig. 1. Prostaglandin (PG) levels in, and PG production by, homogenates of rat and rabbit vasa deferentia (mean + s.e.m. for 6 observations).

The rabbit vas deferens produced significantly more $(P<0 \cdot 01)$ PGF-2 $\alpha$ than PGE-2 or 6-ketoPGF-1 $\alpha$. PGE-2 and 6-keto-PGF-1 $\alpha$ production did not differ significantly (Text-fig. 1). The rat vas deferens produced significantly more $(P<0.01)$ PGE-2 than 6-keto-PGF-1 $\alpha$. PGF- $2 \alpha$ production did not differ significantly from PGE-2 or 6-keto-PGF-1 $\alpha$ production (Text-fig. 1).

\section{Experiment 2}

Neither the rabbit nor rat vas deferens responded directly to any of the prostanoids tested, i.e. PGE-1, PGD-2, PGI-2 in concentrations of up to $1 \mu \mathrm{g} / \mathrm{ml}, \mathrm{PGE}-2$ and PGF- $2 \alpha$ up to $20 \mu \mathrm{g} / \mathrm{ml}, 9,11$ epoxymethano PGH-2, 11,9-epoxymethano PGH-2, ICI 79939 and ICI 81008 up to $10 \mu \mathrm{g} / \mathrm{ml}$.

The rabbit vas deferens responded to noradrenaline by producing rhythmic contractions. Functional activity was assessed by summing the increase in tension produced by each contraction during a 5 -min period after adding noradrenaline. The relationship between functional activity and $\log$ [noradrenaline] was linear for the dose range $1-10 \mu \mathrm{g}$ noradrenaline/ml (correlation coefficient, $r=0.97)$. Noradrenaline $(1-10 \mu \mathrm{g} / \mathrm{ml})$-induced contractions were abolished by phentolamine $\left(10^{-7} \mathrm{M}\right)$, showing that the noradrenaline was acting on $\alpha$-adrenoreceptors. Due to tachyphylaxis, it was difficult to determine the maximum response to noradrenaline. Text-figure 2 shows that in the 


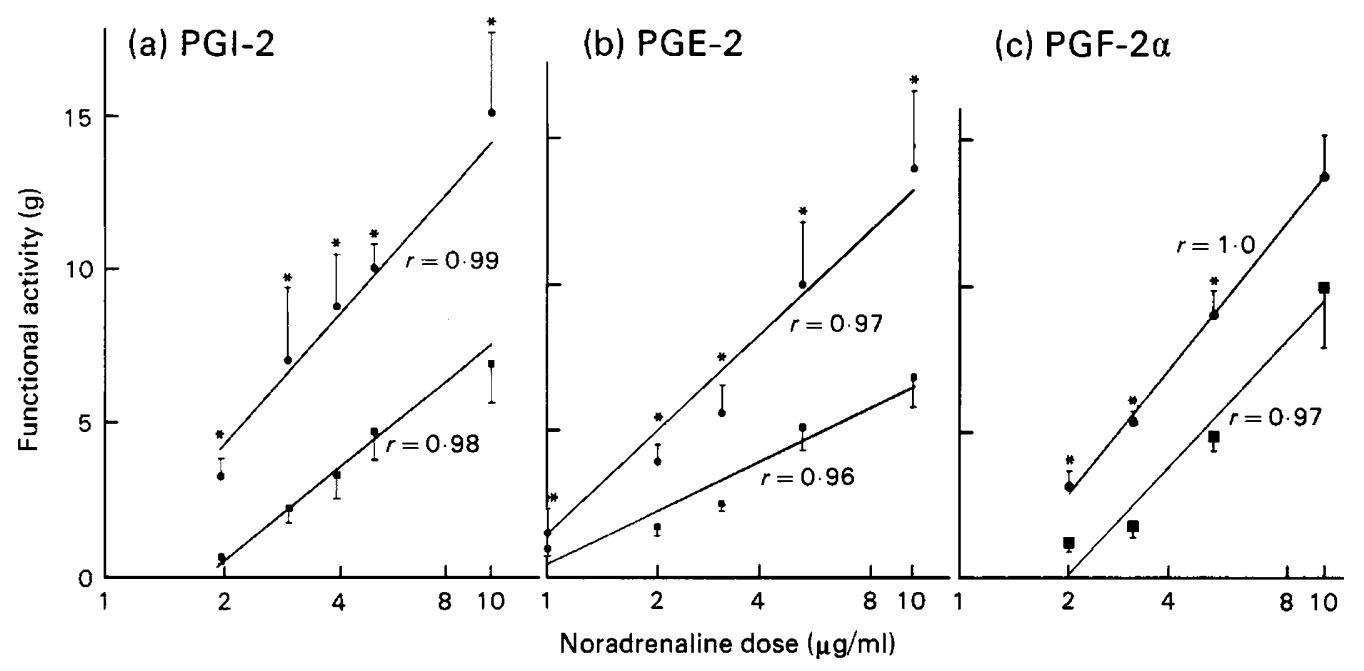

Text-fig. 2. Log dose-response curves of rabbit vasa deferentia to noradrenaline in the absence (a) and presence (O) of (a) $10 \mathrm{ng} \mathrm{PGI-2/ml,} \mathrm{(b)} 200 \mathrm{ng} \mathrm{PGE}-2 / \mathrm{ml}$ and (c) $200 \mathrm{ng} \mathrm{PGF-} 2 \alpha / \mathrm{ml}$. Responses (measured as Functional Activity) were significantly $(P<0.05)$ potentiated by each PG.

presence of $10 \mathrm{ng}$ PGI-2/ml or $200 \mathrm{ng}$ PGE-2/ml or $200 \mathrm{ng}$ PGF-2 $\alpha / \mathrm{ml}$ added $30 \mathrm{sec}$ after a dose of noradrenaline, the dose-response curve to noradrenaline was shifted to the left to similar extents. The displacements produced by PGI-2 and PGE- 2 were not parallel but that produced by PGF- $2 \alpha$ was parallel. After washing out PGI-2, PGE-2 and PGF-2 $\alpha$, the responses to noradrenaline were still enhanced. This effect lasted for up to $30 \mathrm{~min}$. The potentiating doses of PGI-2, PGE-2 and PGF- $2 \alpha$ used were submaximal.

The rat vas deferens responded to noradrenaline by a sustained increase in tone. PGE-1, PGE2, PGI-2 and PGF- $2 \alpha$ in concentrations of up to $400 \mathrm{ng} / \mathrm{ml}$ usually did not affect the response although occasionally potentiation or inhibition $(10-15 \%)$ was seen. The substances 9,11 epoxymethano PGH-2, 11,9-epoxymethano PGH-2, ICI 79939 and ICI 81008 in concentrations of up to $10 \mu \mathrm{g} / \mathrm{ml}$ or PGD-2 $(1 \mu \mathrm{g} / \mathrm{ml})$ did not affect responses of the rabbit and rat vas deferens to noradrenaline.

\section{Experiment 3}

PGE-1 $(80 \mathrm{ng} / \mathrm{ml})$ and PGE-2 $(100 \mathrm{ng} / \mathrm{ml})$ reduced the contractions of the rabbit vas deferens due to field stimulation. PGI-2 also reduced the responses but the dose required was far greater $(600$ $\mathrm{ng} / \mathrm{ml}$ ). When the response, expressed as a $\%$ of that before the addition of $\mathrm{PG}$, was plotted against the $\log$ dose of PG added (Text-fig. 3) PGE-1 and PGE-2 were equipotent whereas PGI-2 was far less potent. Even with $10 \mu \mathrm{g}$ PGI-2/ml, no more than $60 \%$ inhibition was obtained, compared with $80 \%$ inhibition produced by PGE- 2 and PGE-1 at much lower concentrations $(400 \mathrm{ng} / \mathrm{ml})$.

PGD-2, PGF-2 $\alpha$ in concentrations of up to $1 \mu \mathrm{g} / \mathrm{ml}, 9,11$-epoxymethano PGH-2, 11,9-epoxymethano PGH-2, ICI 79939 and ICI 81008 in concentrations of up to $10 \mu \mathrm{g} / \mathrm{ml}$ had no effect on the field-stimulated rabbit vas deferens.

The rat vas deferens was far less sensitive to PGs, and only $20 \%$ inhibition of responses to field stimulation was seen with doses of $400 \mathrm{ng}$ PGE-1 or PGE-2/ml. Further increases of the dose produced no further inhibition. No other prostanoid, i.e. PGD-2, PGF-2 $\alpha$, PGI-2 in concentrations of up to $1 \mu \mathrm{g} / \mathrm{ml}, 9,11$-epoxymethano PGH-2, 11,9-epoxymethano PGH-2, ICI 79939 and ICI 81008 in concentrations of up to $10 \mu \mathrm{g} / \mathrm{ml}$, had any effect on the field-stimulated rat vas deferens. 


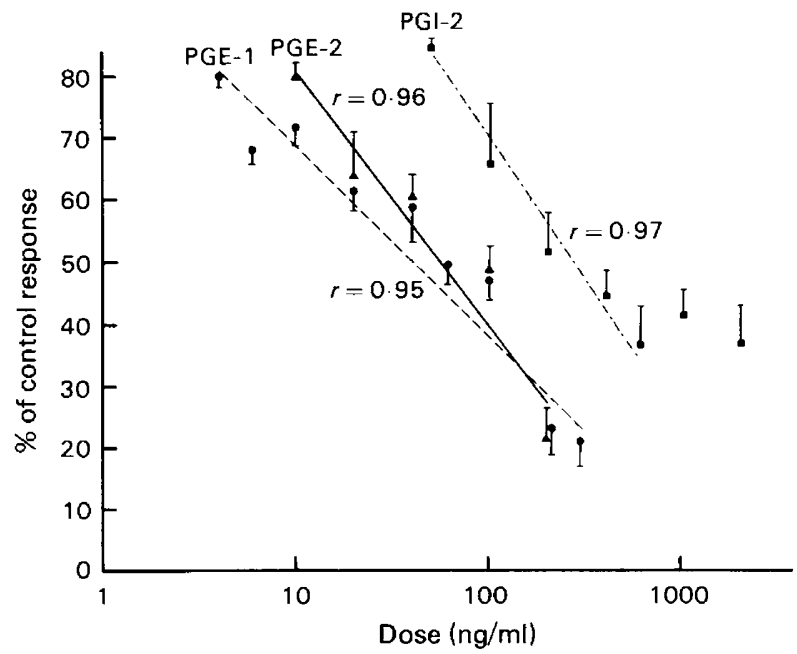

Text-fig. 3. Effect of PGE-1, PGE-2 and PGI-2 on contractions of the rabbit vas deferens due to field stimulation. Responses in the presence of PGs are expressed as a \% of the response before the addition of the PG. The responses to the two highest concentrations of PGI-2 are not included in the regression analysis since the maximum response has been reached.

\section{Discussion}

The major PGs present in rat and rabbit vasa deferentia were PGF-2 $\alpha$ and PGE-2 with lesser quantities of 6-keto-PGF-1 $\alpha$. Gerozissis \& Dray (1980) reported greater levels of PGE-2 (296 $\mathrm{ng} / 100 \mathrm{mg})$ but similar levels of PGF- $2 \alpha(27 \mathrm{ng} / 100 \mathrm{mg})$ in the rat vas deferens. Gerozissis \& Dray (1980) used a different homogenization procedure; they initially froze the tissue in $\mathrm{pH} 7.4$ phosphate buffer at $0^{\circ} \mathrm{C}$. From experiments performed on the guinea-pig uterus (Poyser, 1972) it is clear that even during the homogenization of tissues in an ice-cold aqueous medium PG synthesis is not prevented and the endogenous PG concentrations obtained are higher than when the tissue is immediately placed and homogenized in ethanol as in the present study.

When homogenized and incubated in Krebs' solution rat and rabbit vas deferens tissue synthesized considerable amounts of PGs, from endogenous arachidonic acid, in relation to the endogenous concentrations of PGs contained within the tissue; the PG synthesizing capacities were 3 to 4-fold higher than those of the rat and rabbit uterus, respectively (Poyser \& Scott, 1980; Lytton \& Poyser, 1982b). The major PG synthesized by the rat vas deferens was PGE-2, while the major PG synthesized by the rabbit vas deferens was PGF- $2 \alpha$. However, the rabbit vas deferens contained slightly more PGF- $2 \alpha$ than PGE-2, while this ratio was reversed in the rat vas deferens. Since both the rat and rabbit vas deferens contained considerably more PGF- $2 \alpha$ and PGE-2 than 6keto-PGF- $1 \alpha$, and if endogenous concentrations reflect PG synthesis in vivo, then the intact vas deferens of the rabbit and rat synthesize PGF-2 $\alpha$ and PGE-2 in preference to 6-keto-PGF-1 $\alpha$.

Although the vas deferens of the rabbit and rat can synthesize PGs, we have failed to see any direct effect of PGs or PG analogues on the smooth muscle of this tissue in vitro. PGI-2 was more potent than PGE-2 or PGF- $2 \alpha$ in potentiating responses to noradrenaline in the rabbit vas deferens. PGD-2, 9,11-epoxymethano PGH-2, 11,9-epoxymethano PGH-2, ICI 79939 and ICI 81008 were ineffective. Although both inhibition and potentiation were occasionally observed, no consistent effect of PGs on responses of the rat vas deferens to noradrenaline was seen.

PGE-1, PGE-2 and PGI-2 inhibited the response of the rabbit vas deferens to field stimulation, with PGE-1 and PGE-2 being equipotent and PGI-2 being far less potent. Hedqvist \& von Euler (1972) found that PGE-1 and PGE-2 inhibit the response to field stimulation in cat, rat, guinea-pig 
and rabbit vasa deferentia, while PGF- $2 \alpha$ only caused slight inhibition. The rat vas deferens was far less sensitive to PGE-1 and PGE-2, as found by Hedqvist \& von Euler (1972). PGI-2 had no effect on contractions of the rat vas deferens produced by field stimulation while PGE-1 and PGE-2 produced only a weak inhibitory effect.

In several of our studies on the field-stimulated rat and rabbit vas deferens, phentolamine $(7 \times$ $10^{-6} \mathrm{M}$, an $\alpha$-adrenoreceptor antagonist) and bretylium $\left(10^{-5} \mathrm{M}\right.$, an inhibitor of noradrenaline release from nerve endings) were added to the organ bath at the end of the study (which usually lasted 2-4 h). These inhibitors greatly reduced $(>90 \%)$ the responses of the tissue to field stimulation, suggesting that the responses were due predominantly to stimulation of adrenergic nerves. Since PGE-2 inhibits release of noradrenaline from several tissues, including the transmurally stimulated guinea-pig vas deferens (Hedqvist, 1974), it would appear that PGE-2 and PGE- 1 caused reduction in the response of the field-stimulated rat and rabbit vas deferens by inhibiting noradrenaline output from the sympathetic nerves. (PGI-2 had a similar effect on the rabbit vas deferens but it was much less potent than PGE-1 or PGE-2.) However, the rat vas deferens has adrenergic and non-adrenergic components in the response elicited by field stimulation; these are best seen by using single electrical pulses rather than a train of pulses (McGrath, 1978). The 'non-adrenergic transmitter' is not known. PGE-2 reduces contractions of the rat vas deferens elicited by stimulation of the non-adrenergic component, but has no effect on or, in higher concentrations, ability to potentiate the contractions of the rat vas deferens elicited by the adrenergic component (Bedwani \& Blanning, 1983). Since in the present study, contractions of the rat vas deferens sustained over a 5-sec period were apparently due largely to stimulation of the adrenergic component (by using a train of stimuli), the lack of effect of PGE-2 and PGE-1 on noradrenaline release in the rat vas deferens may be the reason why PGE-2 and PGE-1 had only a weak inhibitory effect on the contractions elicited by field stimulation in our investigations. This inhibitory effect of PGE-2 and PGE-1 may have been due to inhibition of release of the nonadrenergic transmitter. Neither PGI-2 nor any of the other prostanoids tested apparently has this inhibitory action on the release of the non-adrenergic transmitter in the rat vas deferens.

The rabbit vas deferens also appears to have a non-adrenergic component to its contraction elicited by field stimulation (Adebanjo \& Ambache, 1978). However, these components in the rabbit vas deferens are not so well characterized as in the rat vas deferens. Since PGE-2 and PGE-1 had a much greater effect on the rabbit than on the rat vas deferens in reducing contractions elicited by field stimulation using a train of pulses (the sustained contractions appearing to be predominantly adrenergic in nature), PGE-2, PGE-1 and PGI-2 were probably reducing the contractions by inhibiting noradrenaline release from the adrenergic nerves, as reported for the guinea-pig vas deferens (Hedqvist, 1974). However, the effects of PGs on transmitter release in the rabbit vas deferens merit further study.

The nature of the receptors involved in the responses to PGs on the rat and rabbit vas deferens is not known. However, SC 19920, an inhibitor of PGE-2 action on the guinea-pig ileum (Sanner, 1969), inhibits the post-junctional potentiating effects of PGE-1 elicited by noradrenaline on the guinea-pig vas deferens without affecting the pre-junctional inhibitory effects of PGE-1 on contractions elicited by field stimulation. This would indicate that pre- and post-junctional PG receptors are different. This is supported by the present findings that PGI-2 is the most potent postjunctionally while PGE-2 and PGE-1 are the most potent pre-junctionally at producing the appropriate effects, assuming that the PG-mediated events are mediated by single PG receptors at each site. PGF- $2 \alpha$ potentiated the contractions of the rabbit vas deferens elicited by noradrenaline (and was approximately equipotent with PGE-2), but neither of the luteolytic PGF- $2 \alpha$ analogues (ICI 79939 and ICI 81008) had this effect, indicating that the receptors with which PGF-2 $\alpha$ combines on the corpus luteum and the vas deferens are different. Also, neither of the prostanoids with potent TXA-2 activity nor PGD-2 had any pre- or post-junctional effects on the rabbit or rat vas deferens, suggesting that TXA-2 and PDG-2 are without effect on the contractile activity of this tissue. 
The physiological significance of the pre- and post-junctional actions of PGs on the vas deferens is unknown at present. Tomlinson (1980) has found that inhibition of endogenous PG synthesis in the rat vas deferens with aspirin, meclofenamate or indomethacin did not affect the response to field stimulation. This argues against a role for PGs in modulating neurotransmission in the vas deferens, but does not exclude the possibility that PGs produced during coitus may alter the motility of the tissue at that time. Chinoy \& Chinoy (1981) have found that treating rats with PGE1 or PGF- $2 \alpha$ reduces the size of adrenaline-induced contractions of the vas deferens in vitro when compared to those in control rats. They conclude that PGs block $\alpha$-adrenoreceptors in the rat vas deferens. Our results do not support this hypothesis since PGE-1 and PGF-2 $\alpha$ added directly to the organ bath potentiated the effect of noradrenaline. The findings of Chinoy \& Chinoy (1981) are probably due to the decline in testosterone output from the testis (Saksena, El Safoury \& Bartke, 1973), because PG treatment reduces the weight of the vas deferens by $40-50 \%$. In a study of the effects of PGF- $2 \alpha$ on sperm transport, Hafs, Louis \& Stellflug (1974) found that injection of PGF$2 \alpha$ around the testis and epididymis of the rabbit doubles the number of spermatozoa in the vas deferens when compared to controls. In another study, administration of PGF- $2 \alpha$ to rabbits tripled sperm numbers in the vas deferens and doubled sperm output, although treatment with PGF- $2 \alpha$ and PGE-2 daily for 60 days failed to alter sperm production or fertility (Reichard et al., 1978). PGs can therefore affect sperm transport but as yet there appear to be no reports of the action of PGI-2 on sperm transport.

This study was supported by a grant from the M.R.C.

\section{References}

Adebanjo, A.O. \& Ambache, N. (1978) Species variation in vas deferens motor transmission. J. Physiol., Lond. 281, 28P-29P.

Ambache, N. \& Zar, M.A. (1970) An inhibitory effect of prostaglandin E-2 on neuromuscular transmission in the guinea-pig vas deferens. J. Physiol., Lond. 208, $30 P-32 P$.

Badr, F.M., Barcikowski, B. \& Bartke, A. (1975) Effect of castration, testosterone treatment and hereditary sterility on prostaglandin concentrations in the male reproductive system of mice. Prostaglandins 9, 289297.

Bedwani, J.R. \& Blanning, P.E. (1983) Effects of prostaglandin E-2 on fast and slow components of the response of the rat vas deferens to field stimulation. Br. J. Pharmac. 78, 143-150.

Bhagat, B., Dhalla, N.S., Ginn, D., La Montagne, A.E. \& Montier, A.D. (1970) Modification by prostaglandin E-2 (PGE-2) of the response of guinea-pig isolated vasa deferentia and atria to adrenergic stimuli. $B r . J$. Pharmac. 44, 689-698.

Chinoy, N.G. \& Chinoy, M.R. (1981) Infertility induced by prostaglandins in albino rats by adrenergic block in the vas deferens. Int. J. Fertil. 26, 1-7.

Clegg, P.C. (1966) Antagonism by prostaglandins of the responses of various smooth muscle preparations to sympathomimetics. Nature, Lond. 209, 1137-1139.

De Cuminsky, B.S. \& Mercuri, O. (1971) The identification of prostaglandin E-1 in rat seminal vesicle gland. Lipids 6, 278-280.

Dighe, K. K., Emslie, H. A., Henderson, L.K., Rutherford, F. \& Simon L. (1975) The development of antisera to prostaglandins B-2 and F-2 $\alpha$ and their analysis using solid phase and double antibody radioimmunoassay methods. Br. J. Pharmac. 55, 503-514.

Eliasson, R. (1959) Studies on prostaglandin occurrence, formation and biological actions. Acta physiol. scand. 46, Suppl. 158, 1-73.

Gerozissis, K. \& Dray, F. (1980) Prostaglandins dans l'appareil genital du rat male. In Prostaglandins and Reproductive Physiology, pp. 47-63. Eds A. Crastes de Paulet, H. Thaler-Dao \& F. Dray. INSERM, Paris.

Hafs, H.D., Louis, T.M. \& Stellflug, J.N. (1974) Increased sperm numbers in the deferent duct after prostaglandin F-2 $\alpha$ in rabbits. Proc. Soc. exp. Biol. Med. 145, 1120-1124.

Hedqvist, P. (1974) Prostaglandin action in noradrenaline release and mechanical responses in the stimulated guinea-pig vas deferens. Acta physiol. scand. 90, 86-93.

Hedqvist, P. \& von Euler, U.S. (1972) Prostaglandin induced neurotransmission failure in the field stimulated, isolated vas deferens. Neuropharmacology 11, 177-187.

Horton, E.W. \& Thompson, C.J. (1964) Thin-layer chromatography of prostaglandins in extracts of semen and tissues of the male reproductive tract. $\mathrm{Br}$. J. Pharmac. 22, 183-188.

Kelly, R.W. (1978) Prostaglandins in semen: their occurrence and possible physiological significance. Int. J. Androl. 1, 188-200.

Lytton, F.D.C. \& Poyser, N.L. (1982a) Concentrations of PGF- $2 \alpha$ and PGE-2 in the uterine venous blood of rabbits during pseudopregnancy and pregnancy. $J$. Reprod. Fert. 64, 421-429. 
Lytton, F.D.C. \& Poysèr, N.L. (1982b) Prostaglandin production by the rabbit uterus and placenta in vitro. J. Reprod. Fert. 66, 591-599.

Marley, P.B. \& Smith, C.C. (1974a) Mating increases the prostaglandin-like content of male and female reproductive tracts in mice. $J$. Endocr. 61, xxxiv-xxxv.

Marley, P.B. \& Smith, C.C. (1974b) The source and a possible function in fertility of seminal prostaglandin-like material, in the mouse. Br. J. Pharmac. 52, $114 \mathrm{P}$

Marley, P.B. \& Smith, C.C. (1975) Production of prostaglandin-like substance at the time of mating in the rat. Prostaglandins 10, 435-441.

McGrath, J.C. (1978) Adrenergic and 'non-adrenergic' components in the contractile response of the vas deferens to a single indirect stimulus. J. Physiol, Lond. 283, 23-39.

Poyser, N.L. (1972) Production of prostaglandins by the guinea-pig uterus. J. Endocr. 54, 147-159.

Poyser, N.L. (1974) Some aspects of prostaglandins in reproduction. Biochem. Soc. Trans. 2, 1196-1200.

Poyser, N.L. (1983) Differential stimulation of prostaglandin and thromboxane synthesizing capacities in guinea-pig uterus and ovary. Prostaglandins, Leukotrienes and Medicine 10, 163-177.
Poyser, N.L. \& Scott, F.M. (1980) Prostaglandin and thromboxane production by the rat uterus and ovary in vitro during the oestrous cycle. J. Reprod. Fert. 60, 33-40.

Reichard, L.A., Hafs, H.D., Haynes, N.B., Collier, R.J., Kiser, T.E. \& McCarthy, M.S. (1978) Sperm output and serum testosterone in rabbits given prostaglandin F- $2 \alpha$ or E-2. Prostaglandins 16, 135-142.

Saksena, S.K., El Safoury, S. \& Bartke, A. (1973) Prostaglandin E-2 and F-2 $\alpha$ decrease plasma testosterone levels in male rats. Prostaglandins 4, 235-242.

Sanner, J.H. (1969) Antagonism of prostaglandin E-2 by 1-acetyl-2-(8-chloro-10,11-dihydrobenz (b,F) $(1,4)$ oxazepine-10-carbonyl) hydrazine (SC 19920). Archs Int. Pharmacodyn. Ther. 180, 46-56.

Saunders, L. \& Fleming, R. (1975) Mathematics and Statistics, pp. 171-174. Pharmaceutical Press, London.

Tomlinson, D.R. (1980) Do endogenous prostaglandins modulate noradrenergic transmission in the rat isolated perfused vas deferens? Med. Biol. 58, 82-86.

von Euler, U.S. \& Hedqvist, P. (1969) Inhibitory action of prostaglandin E-1 and E-2 on the neuromuscular transmission in the guinea-pig vas deferens. Acta physiol. scand. 77, 510-512.

Received 9 December 1982 